\title{
POLA LUKA PADA KEMATIAN AKIBAT PANAH WAYER DI RSUP PROF. DR. R. D. KANDOU MANADO PERIODE JANUARI SAMPAI OKTOBER 2014
}

\author{
${ }^{1}$ Jaysen Kobstan \\ ${ }^{2}$ Johannis F. Mallo \\ ${ }^{2}$ Djemi Tomuka
}

\author{
${ }^{1}$ Kandidat Skripsi Fakultas Kedokteran Universitas Sam Ratulangi Manado \\ ${ }^{2}$ Bagian Ilmu Kedokteran Forensik dan Medikolegal Fakultas Kedokteran \\ Universitas Sam Ratulangi Manado \\ Email: jaysenkobstan@live.com
}

\begin{abstract}
Panah wayer (a kind of arrow) has become a troubling incident for the citizen of Manado City. People are afraid to do activities outside, especially at night. Wound that caused by this arrow often leads to death if it is punctured into a vital part of the body. However, there are also surviving victims. This study aimed to obtain the pattern of injuries in dead victims caused by this panah wayer. This was a descriptive and retrospective study using visum et repertum as pimary data. The results showed that injuries caused by panah wayer had diverse sizes and depths, depend on the kinetic energy of the arrow itself and the potential energy of the sling itself. Injuries that caused by panah wayer look like a penetrating wound and the hook-like structure at its tip made this arrow hard to repeal and if it is pulled out forcefully a wider rupture at the area of injury can occur.
\end{abstract}

Keywords: pattern of injury, panah wayer

\begin{abstract}
Abstrak: Panah wayer telah meresahkan warga kota Manado dan mengakibatkan ketakutan untuk beraktifitas di luar rumah, terutama di malam hari. Luka akibat panah wayer umumnya mengarah pada kematian bila tertusuk di daerah-daerah tertentu pada bagian tubuh. Penelitian ini bertujuan untuk mendapatkan pola luka pada kematian akibat panah wayer. Penelitian ini bersifat deskriptif retrospektif dengan meggunakan visum et repertum sebagai data primer. Hasil penelitian memperlihatkan bahwa luka akibat panah wayer memiliki ukuran dan kedalaman luka yang beragam berdasarkan energi kinetik dari panah wayer itu sendiri dan energi potensial dari pelontar. Luka yang disebabkan panah wayer memiliki bentuk seperti luka tusuk dan struktur seperti pengait yang terdapat di bagian ujung panah wayer meyebabkan panah wayer sulit untuk dicabut dan jika dicabut secara paksa akan menimbulkan robekan yang lebih besar pada daerah luka.
\end{abstract}

Kata kunci: pola luka, panah wayer

Panah wayer telah menjadi kejadian yang meresahkan warga kota Manado. Warga kota Manado merasa ketakutan untuk beraktifitas di luar rumah, terutama di malam hari. Hal ini dikarenakan maraknya penggunaan panah wayer dalam aktifitas penyerangan yang dilakukan oleh seseorang atau sekelompok orang. ${ }^{1}$ Beberapa daerah di kota manado seperti Mahakeret Barat, Titiwungen Utara,
Tuminting, dan Wonasa merupakan daerah rawan serangan panah wayer. ${ }^{2}$

Bentuk panah wayer yang tajam menyebabkan luka akibat panah wayer termasuk dalam luka tusuk (penetrating wound) dan dalam pengobatannya biasanya dijumpai beberapa kesulitan seperti infeksi dan kesulitan mencabut panah wayer akibat struktur gerigi yang merusak jaringan otot. Luka akibat panah wayer umumnya 
mengarah pada kematian bila tertusuk di daerah-daerah tertentu pada bagian tubuh, namun ada juga beberapa korban yang selamat. Hal ini menjadi pertanyaan yang cukup mengundang rasa penasaran dari masyarakat umum.

\section{METODE PENELITIAN}

Penelitian yang dilakukan menggunakan metode deskriptif retrospektif. Penelitian dilakukan di RSUP Prof. Dr. R. D. Kandou Manado terhadap korban pembunuhan akibat panah wayer dengan variabel visum et repertum, pola luka, dan letak cedera.

Data kasus korban pembunuhan akibat panah wayer diambil berdasarkan hasil otopsi dan rekam medik, dan kemudian diolah dengan mencari pola luka yang paling sering menyebabkan kematian pada pada kasus pembunuhan akibat panah wayer. Pengolahan data dilakukan secara manual dan pengkajian data diolah dalam bentuk diagram.

\section{HASIL PENELITIAN}

Penelitian dilakukan selama periode September 2014 sampai Desember 2014 di Bagian Forensik dan Medikolegal BLU RSUP Prof. Dr. R. D Kandou Manado, dengan data tambahan yang diperoleh dari Polresta Manado. Penelitian retrospektif yang dilakukan untuk memperoleh kasus kematian akibat panah wayer selama periode Januari 2014 sampai Oktober 2014. Terdapat 58 kasus yang tercatat di Polresta Manado. Dari 58 kasus tersebut terdapat tiga kasus yang memiliki keterangan nasib korban (mengalami luka atau meninggal dunia) dan dari ketiga kasus tersebut terdapat dua korban yang meninggal, namun hanya satu kasus yang dibuat pemeriksaan otopsi (Visum et Repertum). Data yang berjumlah 58 kasus memiliki satu kasus yang memenuhi kriteria inklusi dan dua kasus yang memenuhi kriteria eksklusi.

Penelitian ini mendapatkan satu sampel yang memenuhi kriteria inklusi penelitian. Kasus terjadi pada tanggal 31 Januari 2014, korban mengalami luka pada bagian tubuh daerah dada kanan, dada kiri, perut kanan, perut kanan, lengan atas kiri, dan punggung. Luka akibat panah wayer di daerah dada kanan $12 \mathrm{~cm}$ dari GPD, $27 \mathrm{~cm}$ dibawah puncak bahu, berbentuk bulat, berdiameter $1 \mathrm{~cm}$. Luka di daerah perut kanan $7 \mathrm{~cm}$ dari GPD, $49 \mathrm{~cm}$ di bawah puncak bahu, berbentuk bulat, berdiameter $1 \mathrm{~cm}$.

\section{BAHASAN}

Pada hasil penelitian ini didapatkan satu kasus kematian akibat panah wayer selama periode Januari sampai Oktober 2014 di Bagian Forensik dan Medikolegal BLU RSUP Prof. R. D Kandou Manado. Berdasarkan data yang diperoleh dari Polresta Manado, terdapat tiga kasus yang menyatakan status korban, satu korban hanya mengalami luka sedangkan dua korban meninggal dunia. Sedikitnya kasus yang menyatakan status korban dan permintaan Visum et Repertum membuat penyilidikan sulit untuk dilanjutkan. Hal ini mengungkapkan bahwa minimnya peran Visum et Repertum dalam proses penyelidikan. Kasus yang diteliti pada penelitian ini hanya terhenti pada tahap I penyelidikan.

Data diambil dari hasil pemeriksaan otopsi (Visum et Repertum). Pemeriksaan yang dilakukan mencakup pemeriksaan luar dan pemeriksaan dalam. Pada pemeriksaan luar didapatkan daerah-daerah pada bagian tubuh yang ditembus oleh panah wayer, sedangkan pada pemeriksaan dalam ditemukan organ-organ tubuh yang mengalami luka akibat tertembus panah wayer. Visum et Repertum yang dilakukan pada korban bertujuan untuk mencari sebab utama kematian dan luka-luka atau penyebab lain yang memperberat penyembuhan atau mempercepat proses kematian korban.

Pada penelitian didapatkan alur luka pada luka yang terletak pada daerah dada kanan, yaitu luka menembus kulit, jaringan bawah kulit, masuk ke rongga dada menembus sekat rongga dada, masuk ke rongga perut menembus hati dengan ukuran 1x0,5 cm, alur berjalan dari samping kanan 
depan ke samping kiri belakang membentuk sudut $45^{\circ}$ dengan panjang alur luka $12 \mathrm{~cm}$.

Hepar sangat kaya pembuluh darah sehingga trauma yang terjadi di hepar dapat menyebabkan perdarahan dan syok hemoragik. Trauma dapat menyebabkan kebocoran empedu lewat kanalikuli. Jika rongga peritoneum terkontaminasi darah atau empedu, dapat timbul tanda peritonitis seperti nyeri tekan dan nyeri lepas pada abdomen, otot-otot abdomen kencang, dan tidak ada gerakan peristaltis. ${ }^{3}$ Berdasarkan alur luka yang didapatkan dari hasil penelitian, dapat disimpulkan bahwa panah wayer yang menembus hepar dengan lokasi berawal dari bilik kanan menuju lobus kiri dengan sudut empat puluh lima derajat menembus vena kava inferior, vena hepatika, prosesus kaudatus, dan ligamentum teres.

Luka yang terdapat pada daerah perut kanan memiliki alur luka yang menembus kulit, jaringan bawah kulit, masuk ke rongga perut menembus usus halus, alur luka berjalan dari samping kanan depan ke samping kiri belakang, ukurang panjang alur 8,5 cm. Dalam rongga perut terdapat bekuan darah sebanyak $1.100 \mathrm{ml}$. Perdarahan ini dapat disebabkan oleh karena terjadi laserasi dari mukosa yang dapat menyebabkan hematemesis dan dapat mengakibatkan kegagalan fungsi jantung. ${ }^{4}$ Luka tusuk dan luka tembak kecepatan rendah menyebabkan kerusakan jaringan dengan laserasi dan memotong. ${ }^{5}$ Luka tusuk yang terjadi di usus biasanya tidak langsung menyebabkan kematian, tapi menyebabkan kematian secara perlahan.

Pada hasil otopsi korban tidak tercantum hasil pemeriksaan laboratorium, dikarenakan kandungan timbal $(\mathrm{Pb})$ yang terkandung dalam air aki mobil yang biasanya dioleskan pada bagian ujung panah wayer tidak cukup untuk menimbulkan keracunan timbal. Seseorang dikatakan keracunan timbal jika terpapar timbal dalam dosis tinggi dan dalam durasi yang lama. ${ }^{6}$ Normal kadar $\mathrm{Pb}$ dalam darah kurang dari $60 \mu \mathrm{g} / 100 \mathrm{ml}$. Bila $>70 \mu \mathrm{g} / 100$ $\mathrm{ml}$ berarti terdapat pemaparan abnormal.
Bila kadar Pb dalam darah $>100 \mu \mathrm{g} / 100 \mathrm{ml}$ berarti telah terjadi keracunan timbal. ${ }^{7}$

Struktur ujung panah wayer yang menyerupai gerigi atau kail ikan akan menyebabkan terkaitnya ujung panah wayer pada lapisan kulit, otot, atau organ tubuh. Pencabutan secara paksa dari panah wayer yang telah tertancap pada tubuh akan menyebabkan robekan yang lebih luas pada daerah trauma. Biasanya panah wayer yang dicabut secara paksa akan meninggalkan bekas luka yang berbentuk luka pada jaringan otot. Pencabutan panah wayer harus dilakukan oleh dokter spesialis bedah untuk menghindari komplikasi atau faktorfaktor yang dapat memperburuk kondisi korban. Jika tidak dicabut, panah wayer akan menyebabkan rasa nyeri yang terus menerus dan bisa menimbulkan disabilitas jika terkena pada anggota gerak tubuh.

Dampak yang paling sering disebabkan oleh panah wayer ialah infeksi karena panah wayer dibuat dan digunakan secara tidak higienis dan kandungan bakteri yang terkandung dalam anak panah wayer dapat masuk ke jalur sistemik peredaran darah dan menyebabkan infeksi.

Panah wayer yang dibuat dari bahan yang tidak steril seringkali menyebabkan infeksi. Dengan hancurnya perlindungan yang disediakan oleh kulit dan membran mukosa, bakteri yang menempati lingkungan di luar tubuh dapat memasuki daerah luka dan menyebabkan infeksi lokal. Bakteri yang terkandung pada objek yang menyebabkan luka (panah wayer) juga dapat menyebabkan infeksi lokal. Bakteri yang biasanya ditemukan pada infeksi primer dari suatu luka adalah streptococci, staphylococci, Escherichia coli, Proteus vulgaris. Bakteri-bakteri yang biasa terdapat pada lapisan kulit tersebut biasanya ditemukan juga pada lapisan kulit yang terluka.

Karena terdapat selang waktu antara kontaminasi luka dan waktu respon antibodi oleh tubuh beragam, maka sulit untuk menentukan apakah infeksi yang terjadi bersamaan dengan saat terjadinya luka (infeksi primer) atau akibat terkontaminasi bakteri saat setelah terjadi 
luka (infeksi sekunder).

Dengan menggunakan hukum kekekalan energi, jarak yang ditembakkan, kekuatan tembakan, percepatan tembakan, serta kedalaman luka dapat diketahui. Untuk mencari jarak panah wayer dilepaskan, maka harus diketahui kecepatan awal dari panah wayer ketika ditembakkan, dan dapat dihitung menggunakan persamaan $1 / 2 \mathrm{~K} . \mathrm{X}^{2}=1 / 2 \mathrm{MV}^{2}$ dimana $\mathrm{K}$ ialah koefisien elastisitas dari karet yang digunakan sebagai busur, $\mathrm{X}$ ialah elastisitas maksimum dari karet tersebut, $\mathbf{M}$ ialah massa panah wayer, dan $\mathrm{V}$ ialah kecepatan awal panah wayer ketika dilepaskan. ${ }^{8}$ Persamaan ini digunakan untuk mencari nilai $\mathrm{V}_{0}$ atau kecepatan awal panah wayer ketika dilepaskan. Untuk mencari jarak penembak dan korban, dapat menggunakan persamaan $1 / 2 \mathrm{MV}^{2}=\mathrm{F}_{\text {udara }} \cdot \mathrm{X}_{\text {udara }}+$ $\mathrm{F}_{\text {tubuh. }} \mathrm{X}_{\text {tubuh }}$ dimana $\mathrm{M}$ ialah massa panah wayer, $\mathrm{V}$ ialah kecepatan awal ketika panah wayer dilepaskan, $F_{\text {udara }}$ ialah gaya gesek yang ditimbulkan udara, $\mathrm{X}_{\text {udara }}$ ialah jarak yang ditempuh panah wayer sebelum mencapai sasaran, $F_{\text {tubuh }}$ ialah gaya gesek oleh tubuh, dan $\mathrm{X}_{\text {tubuh }}$ ialah jarak yang ditempuh panah wayer ketika memasuki tubuh hingga berhenti total. ${ }^{8}$ Persamaan ini dapat digunakan untuk mencari jarak antara penembak dan korban atau berapa kedalaman luka jika panah wayer dilepaskan dari jarak tertentu.

Contoh penggunaan kedua persamaan ini ialah ketika ingin mencari jarak penembak dan korban dilihat dari alur luka pada bagian tubuh dada kanan. Dengan pengandaian nilai koefisien elastisitas, elastisitas maksimum, massa panah wayer, gaya gesek udara, dan gaya gesek tubuh maka didapatkan sebagai berikut:

$$
\begin{aligned}
& \mathrm{K}=13 \\
& \mathrm{X}_{0}=0,5 \mathrm{~m} \\
& \mathrm{M}=0,22 \mathrm{~kg} \\
& 1 / 2 \mathrm{~K} \cdot \mathrm{X}^{2}=1 / 2 \mathrm{MV}^{2} \\
& 1 / 2 \cdot 13 \cdot 0,5^{2}=1 / 2 \cdot 0,22 \cdot \mathrm{V}_{\mathrm{o}}{ }^{2} \\
& \mathrm{~V}_{\mathrm{o}}=3,83 \mathrm{~m} / \mathrm{s}
\end{aligned}
$$

Ketika nilai $\mathrm{V}_{0}$ telah didapatkan maka untuk menghitung jarak antara penembak dan korban, dengan pengandaian massa panah wayer, gaya gesek udara, dan gaya gesek tubuh ialah:

$$
\begin{aligned}
& \mathrm{M}=0,22 \mathrm{~kg} \\
& \mathrm{~V}_{0}=3,83 \mathrm{~m} / \mathrm{s} \\
& \mathrm{F}_{\text {udara }}=0,3 \mathrm{~N} \\
& \mathrm{~F}_{\text {tubuh }}=10 \mathrm{~N} \\
& \mathrm{X}_{\text {tubuh }}=0,12 \mathrm{~m} \text { (kedalaman luka) } \\
& 1 / 2 \mathrm{MV}^{2}=\mathrm{F}_{\text {udara }} \cdot \mathrm{X}_{\text {udara }}+\mathrm{F}_{\text {tubuh }} \cdot \mathrm{X}_{\text {tubuh }} \\
& 1 / 2 \cdot 0,22 \cdot 3,83^{2}=0,3 \cdot \mathrm{X}_{\text {udara }}+10.0,12 \\
& \mathrm{X}_{\text {udara }}=1,3 \mathrm{~m}
\end{aligned}
$$

Berdasarkan hasil perhitungan di atas maka diperoleh jarak antara penembak dan korban sebesar 1,3 m. Untuk menghitung percepatan, maka dapat digunakan persamaan:

$$
\mathrm{A}=\frac{\mathrm{K} . \mathrm{X}}{\mathrm{M}}
$$

dimana A ialah akselerasi atau percepatan, $\mathrm{K}$ ialah koefisien elastisitas karet, $\mathrm{X}$ ialah elastisitas maksimum karet, dan $\mathrm{M}$ ialah massa panah wayer. ${ }^{8}$ Contoh penggunaan persamaan ini dengan menggunakan angka pengandaian diatas ialah:

$$
\begin{aligned}
& \mathrm{K}=13 \\
& \mathrm{X}=0,5 \mathrm{M} \\
& \mathrm{M}=0,22 \mathrm{~kg} \\
& \mathrm{~A}=\frac{K \cdot X}{M} \quad \mathrm{~A}=\frac{13 \cdot 0,5}{0,22} \\
& \mathrm{~A}=29,5 \mathrm{~m} / \mathrm{s}
\end{aligned}
$$

Berdasarkan perhitungan di atas, maka percepatan yang diperoleh ialah 29,5 m per detik.

\section{SIMPULAN}

Berdasarkan hasil yang diperoleh dapat disimpulkan bahwa luka akibat panah wayer memiliki ukuran dan kedalaman luka yang beragam berdasarkan energi kinetik dari panah wayer itu sendiri dan energi potensial dari pelontar.

Luka yang disebabkan oleh panah wayer tergolong luka yang dapat mengancam nyawa karena seperti halnya peluru, ketika panah wayer memasuki tubuh, panah wayer akan menembus jaringan kulit, otot, dan organ, dan akan berhenti ketika kehilangan energi kinetiknya. Luka yang disebabkan panah wayer memiliki bentuk seperti luka tusuk, 
namun struktur seperti pengait yang terdapat di bagian ujung panah wayer meyebabkan panah wayer sulit untuk dicabut dan jika dicabut secara paksa akan menimbulkan robekan yang lebih besar pada daerah luka. Panah wayer juga dapat menyebabkan infeksi karena penggunaan bahan yang tidak steril dan pada umumnya sudah berkarat atau dilumuri dengan zat kimia (seperti timbal) atau unsur-unsur lain.

Dengan menggunakan persamaan hukum kekekalan energi, jarak penembak panah wayer dan korban, percepatan panah wayer di udara, serta kedalaman luka dapat diukur. Pada kasus ini, jarak penembak dan korban 1,3 m, dengan percepatan panah wayer sebesar $29,5 \mathrm{~ms}$.

\section{SARAN}

Pada penelitian selanjutnya hendaknya menggunakan sampel yang lebih banyak sehingga dapat menemukan pola luka yang lebih akurat.

Perlu dilakukan penelitan mendalam terhadap panah wayer itu sendiri, sehingga dapat mengetahui spesifikasi panah wayer secara ilmiah.

Sebaiknya pihak kepolisian mengajukan permintaan Visum et Repertum bagi setiap korban meninggal dengan panah wayer agar dapat diketahui penyebab jelas pada setiap kasus kematian

\section{DAFTAR PUSTAKA}

1. Abdussalam HR, Desasfuryanto A. Buku Pintar Forensik Jakarta: PTIK Press; 2014.

2. Sendow M. Kompasiana. [Online]. 2014. [cited 2014 Sept 12]. Available from: http://sosbud.kompasiana.com/2014/05/ 13/maraknya-panah-wayer-airsoft-gundan-pistol-di-manado-655323.html.

3. Idries A. Pedoman Ilmu Kedokteran Forensik Jakarta: Binarupa Aksara, 1997.

4. Tedeschi GC, Eckert WG, Tedeschi LG, editors. Forensic Medicine. London: W. B. Saunders Company, 1977.

5. Kurniawati

A. http://andiriakurniawati.blogspot.com. [Online].; 2012 [cited 2014 Dec 11]. Available from: http://andiriakurniawati.blogspot.com/2 012/02/hepar-anatomi-danfisiologi.html.

6. Burhani SN. Scribd. [Online]. [cited 2014 Dec 11]. Available from: https://www.scribd.com/doc/13834943 7/Definisi-Pemeriksaan-LaboratoriumSederhana\#download.

7. fau.pearlashes.com. [Online]. [cited 2014 Dec 11]. Available from: http://fau.pearlashes.com/anatomy/Cha pter\%2038/Chapter\%2038_files/image 013.jpg.

8. Syarifudin ST. Intisari Fisika untuk SMA Tangerang: Scientific Press, 2007. 